\title{
KEDAULATAN NEGARA \\ DALAM KERANGKA HUKUM INTERNASIONAL KONTEMPORER
}

\author{
Sigit Riyanto \\ Fakultas Hukum UGM. Email: \\ riyanto@gadjahmada.edu.
}

\begin{abstract}
This research aimed at comprehensively analize the concept of State sovereignty and its application in the contemporary international law. In this research the concept of State sovereignty and relevant rules of international law have been analysed accordingly. Legal materials that thoroughly considered and studied in the context of this research were relevant international rules and facts embodied in international customs, general principles of law, international treaties, conventions, declarations and decisions of international organisation, recommendations, guiding principles, plan of actions, executive committee decisions, reports, academic publications, proceedings and working papers. Legal materials obtained were classified systematically and interptreted and evaluated thouroughly. The formulation concerning the the relevant facts and international legal frameworks pertainingto the concept of sovereignty based upon interpretation and evaluation of the existing legal materials. Eventually, the concept of sovereignty in the contemporary international society could be revealed accordingly. The State sovereignty is relational and open concept; not an insular or narrow and closed concept. A visionary discourse is needed to reinvent the valid interpretation of sovereignty in the framework of interdependence among States in the present international system. Sovereignty shall be interpreted as responsibility of the national authority. In this context State as an agent and manifestation of people sovereignty has the primary responsibility to protect, respect and fulfill the citizen rights accordingly and accountable to the international society.
\end{abstract}

Key Words: Sovereignty, International Law, Responsibility.

\begin{abstract}
Abstrak
Penelitian ini dilakukan untuk melakukan kajian mendalam dan akurat tentang konsep kedaulatan negara dan penerapannya dalam kerangka hukum internasional kontemporer. Bahan kajian utama penelitian ini adalah keputusan dan fakta-fakta hukum internasional yang relevan, yang tertuang dalam hukum internasional kebiasaan, prinsip-prinsip umum hukum, perjanjian internasional, konvensi, deklarasi dan keputusan-keputusan organisasi internasional, rekomendasi organisasi internasional, prinsip-prinsip panduan, buku panduan, rencana aksi, keputusan komite eksekutif, laporan, publikasi ilmiah, proceedings seminar, dan kertas kerja. Setelah dilakukan klasifikasi dan sistematisasi bahan penelitian, berikutnya dilakukan interpretasi dan evaluasi. Berdasarkan interpretasi dan evaluasi tersebut, dilanjutkan dengan preskripsi untuk merumuskan kejelasan tentang konteks situasi faktual dan kerangka hukum internasional yang relevan. Pada akhirnya dapat diketahui konsep kedaulatan negara dalam masyarakat internasional terkini. Kedaulatan bersifat relasional dan terbuka; bukan suatu konsep yang "insular" atau sempit dan tertutup. Suatu wacana visioner diperlukan untuk merekonstruksi kedaulatan negara dalam kerangka interdependensi antar negara dalam sistem internasional terkini. Kedaulatan negara harus dimaknai sebagai tanggung jawab otoritas nasional. Dalam konteks ini negara sebagai agen dan manifestasi dari kedaulatan rakyat, bertanggungjawab untuk melindungi, menghormati dan memenuhi hak-hak warganya serta harus mempertanggungjawabkan mandatnya kepada masyarakat internasional.
\end{abstract}

Kata Kunci: Kedaulatan Negara, Hukum Internasional, Tanggungjawab.

\section{A. Pendahuluan}

Kedaulatan negara merupakan konsep yang sangat menarik dan inspiratif dalam wacana akademis dalam bidang hukum dan politik internasional. Dari waktu ke waktu dapat dicatat tentang perdebatan yang sangat dinamis dan provokatif tentang konsep kedaulatan negara dalam hukum internasional. Tampaknya, diperlukan reinterpretasi tentang makna kedaulatan negara dalam konteks sistem hukum internasional terkini; utamanya jika dikaitkan dengan fenomena kegagalan otoritas nasional dalam memberikan 
perlindungan warganya serta makin maraknya globalisasi dan kerjasama internasional yang makin intensif di berbagai wilayah dunia. Pada saat bersamaan, kini juga makin deras aliran pemahaman yang memposisikan negara sebagai instrumen yang melayani kepentingan rakyat dan bukan sebaliknya. Pemahaman tradisional tentang konsep kedaulatan negara, dewasa ini juga dianggap sebagai kendala penanganan krisis kemanusiaan secara efektif dan perlindungan kepentingan dan hak-hak mendasar warga negara.

Penelitian ini bertujuan untuk mengkaji secara mendalam dan akurat tentang konsep kedaulatan negara dan penerapannya dalam kerangka hukum internasional kontemporer.

\section{B. Metode Penelitian}

Penelitian ini merupakan kajian terhadap permasalahan berdasarkan kerangka hukum internasional. Bahan-bahan kajian dalam penelitian ini meliputi :

1. ketentuan-ketentuan hukum internasional yang tertuang dalam hukum internasional kebiasaan (customary international law), prinsip-prinsip umum hukum (the general principles of law) perjanjian internasional, konvensi, deklarasi dan keputusan-keputusan organisasi internasional;

2. rekomendasi organisasi internasional, prinsipprinsip panduan (Guiding Principles), catatan notulen (risalah) proses pembentukan perjanjian internasional, buku panduan ( handbooks) yang diterbitkan oleh organisasi internasional, rencana aksi internasional ( international plan of actions), laporan (reports) organisasi internasional, dan lembaran fakta (facts sheet) yang dipublikasikan oleh organisasi internasional;

3. pendapat para ahli yang kompeten yang dipublikasikan dalam buku,jurnal ilmiah, proceedings seminar internasional, dan kertas kerja (working papers).

Setelah dilakukan klasifikasi dan sistematisasi terhadap bahan penelitian, berikutnya dilakukan analisis melalui interpretasi dan evaluasi. Berdasarkan interpretasi dan evaluasi tersebut, dilanjutkan dengan preskripsi untuk merumuskan kejelasan tentang konteks situasi faktual dan kerangka hukum internasional yang relevan.

\section{Hasil Penelitian dan Pembahasan.}

Sesuai dengan masalah pokok dan tujuan penelitian yang telah ditetapkan di atas, uraian dalam naskah pembahasan ini difokuskan pada empat tema pokok yang relevan. Keempat tema tersebut adalah: Pertama, tentang kedaulatan negara sebagai konsep dasar dalam hukum internasional. Kedua, perolehan kedaulatan negara menurut hukum internasional. Ketiga, kedaulatan negara dalam hubungan antar negara. Keempat, mebahas kedaulatan negara dalam kaitannya dengan globalisasi dan interdependensi internasional.

\section{Kedaulatan Negara sebagai Konsep Dasar Hukum Internasional}

Ajaran filosofis yang paling mengesankan tentang kedaulatan adalah bahwa, kedaulatan merupakan kekuasaan absolut atas suatu wilayah tertentu. Kekuasaan absolut atas wilayah tersebut menjadi dasar bagi pembentukan negara (Jenik Radon, 2004: 1995). Pemahaman tentang konsep kedaulatan negara ini sangat membantu dalam mencermati dan mengevaluasi kedudukan negara dalam konteks hubungan internasional yang sangat dinamis.

Dalam wacana akademik, tampaknya tidak dapat ditetapkan suatu definisi tunggal tentang kedaulatan. Terminologi kedaulatan memiliki beragam makna dan penafsiran. Istilah kedaulatan seringkali diberi makna berbedabeda oleh akademisi, jurnalis, politisi, pejabat internasional, juris dan kalangan lain dengan latar belakang profesi, budaya, dan disiplin intelektual yang juga berbeda-beda (Winston P. Nagan, \& Craig Hammer. 2004: 143-145). Istilah ini dapat memiliki makna berbeda bagi orang yang berbeda, yang masing-masing memiliki latar belakang beragam pula. Istilah kedaulatan mungkin memiliki makna berbeda dalam ilmu hukum, ilmu politik, sejarah, filsafat, dan bidang-bidang lain yang berkaitan dengannya.

Ada berbagai pendekatan, beragam kategorisasi dan berbagai variasi tentang penggunaan konsep kedaulatan. Kedaulatan dapat merujuk pada kedaulatan domestik, kedaulatan interdependensi, kedaulatan hukum internasional, dan kedaulatan negara yang absolut. Kedaulatan sebagai konsep yang menunjuk pada kekuasaan utama dan tertinggi untuk memutuskan dapat dianalisis dan dikualifikasikan berdasarkan perspektif/sudut pandang unsur-unsur yang berhadapan (diametral), yaitu kedaulatan hukum atau kedaulatan politik; kedaulatan internal atau eksternal; kedaulatan yang tunggal atau kedaulatan yang dapat dibagi; kedaulatan pemerintah atau rakyat (Dan Sarooshi, 2004: 25 ; Jens Bartelson , 2006: 463 ). 
James J Sheehan mengemukakan pandangan yang sangat kritis, bahwa salah satu permasalahan terkait konsep kedaulatan (sovereignty) adalah tentang definisi. Kedaulatan adalah suatu konsep politik, namun demikian, tidak seperti halnya konsep tentang demokrasi atau monarki; kedaulatan bukanlah tentang tempat kekuasaan itu berada. Kedaulatan tidak sama halnya dengan parlemen atau birokrasi; karena kedaulatan tidak menggambarkan institusi-institusi yang menjalankan kekuasaan. Kedaulatan juga tidak dapat disamakan dengan tertib hukum (order) maupun keadilan (justice) ; karena kedaulatan tidak menggambarkan tujuan dari pelaksanaan kekuasaan. Kedaulatan adalah suatu hal dan meliputi banyak hal (the one or the many) (James J Sheehan, 2006: 419).

Konsep tentang kedaulatan adalah suatu hal yang berkaitan dengan hubungan antara kekuasaan politik dan bentuk-bentuk otoritas lainnya. Kedaulatan dapat dipahami dengan mencermati bahwa ; pertama, kekuasaan politik adalah berbeda dengan kerangka organisasi atau otoritas lain di dalam masyarakat seperti religius, kekeluargaan dan ekonomi; kedua, kedaulatan menegaskan bahwa otoritas publik semacam ini bersifat otonom dan sangat luas (autonomous and preeminent) sehingga lebih tinggi (superior) dari institusi yang ada dalam masyarakat yang bersangkutan dan independen atau bebas dari pihak luar.

Wacana tentang konsep kedaulatan negara seringkali juga ditandai dengan cara menetapkan otoritas politik yang utama; antara lembaga domestik dan otonomi internasional. Dalam praktik internasional, hal ini dapat dilihat dari pengakuan dan tindakan kolektif negaranegara dalam menyelesaikan suatu masalah yang melibatkan otoritas lembaga domestik dan otoritas internasional. Dalam kaitannya dengan kedaulatan, dapat dikemukakan catatan bahwa hukum merupakan aspek yang sangat penting. Hukum merupakan fondasi atau landasan bagi terciptanya ketertiban politik, bahkan ada pendapat yang menyatakan bahwa hukum merupakan "the sole guarantor of the continuity of "civilization "(Anthony Pagden, 2002 dalam James J Sheehan, 2006: 42-43). Tata hukum dapat menjadi instrumen untuk menjamin keberlanjutan keberadaban. Kristalisasi teoritik tentang hubungan antara hukum dengan kedaulatan dapat ditemukan dalam doktrin tentang kedaulatan sebagaimana dikemukakan oleh Jean Bodin pada abad keenambelas. Dalam hal ini Jean Bodin mengemukakan doktrin atau ajaran bahwa kedaulatan merupakan sumber utama untuk menetapkan hukum. Kedaulatan merupakan sumber otoritas yang berada pada aras tertinggi dalam hirarki hukum (legal hierarchy).

Adanya berbagai variasi tentang makna dan penggunaan konsep kedaulatan negara, tidak mengurangi arti penting konsep ini dalam sistem hukum internasional dan teori hubungan internasional. Kedaulatan merupakan salah satu konsep mendasar dalam hukum internasional (one of the fundamental concepts in international law). Dalam kerangka hubungan antar negara, kedaulatan juga merujuk pada pengertian kemerdekaan (independence) dan vice versa. Suatu negara merdeka adalah negara yang berdaulat. Negara yang berdaulat adalah negara merdeka dan tidak berada di bawah kekuasaan negara lain (Jens Bartelson, 2006 : 463).

Dalam hukum internasional, kedaulatan negara (state sovereignty) dan kesederajatan (equality) antar negara merupakan konsep yang diakui dan menjadi dasar bekerjanya sistem hukum internasional itu. Hukum internasional secara tradisional mengakui bahwa negara sebagai entitas yang merdeka dan berdaulat, berarti negara itu tidak tunduk pada otoritas lain yang lebih (Miguel González Marcos, 2003: 1; Martin Dixon \& Robert Mc. Corquodale, 2000,: 248 ). Kedaulatan dan kesederajatan negara merupakan atribut yang melekat pada negara merdeka sebagai subyek hukum internasional. Pengakuan terhadap kedaulatan negara dan kesederajatan antar negara juga merupakan dasar bagi personalitas negara dalam sistem hukum internasional (lan Brownlie, 1990: 287 ).

Kedaulatan mendasari beberapa hak yang diakui oleh hukum internasional seperti misalnya; hak kesederajatan (equality), yurisdiksi wilayah ( territorial jurisdiction), hak untuk menentukan nasionalitas bagi penduduk di wilayahnya, hak untuk mengijinkan dan menolak atau melarang orang untuk masuk dan keluar dari wilayahnya, hak untuk melakukan nasionalisasi (R.C. Hingorani, 1982: 117-118).

Dalam kepustakaan hukum internasional, konsep kedaulatan negara juga menjadi dasar salah satu doktrin yang dikenal dengan istilah Act of State Doctrine. Doktrin ini di Inggris dikenal dengan istilah: "the Sovereign Act Doctrine" . Doktrin hukum yang muncul pada abad ke sembilan belas (XIX) ini menegaskan: 
"Every sovereign State is bound to respect the independence of every sovereign State, and the courts of one country will not sit in judgment on the acts of the government of another done within its own territory". Menurut Act of State Doctrine , setiap Negara berdaulat wajib mengormati kemerdekaan negara berdaulat lainnya (Robert I Bledsoe \& Boleslaw A Boczek, 1987: 3 ).

Kedaulatan merupakan konsep yang sangat penting dalam tertib hukum domestik maupun internasional, dan merupakan titik persinggungan antara kedua sistem tertib hukum tersebut. Kedaulatan negara merupakan salah satu norma fondasional dalam sistem hukum internasional. Konsekuensinya, konsep tentang negara yang berdaulat sebagai kesatuan otoritas yang tidak tunduk pada pihak manapun merupakan penyangga sistem tata hukum internasional yang menjunjung tinggi prinsip non-intervensi dan kesepakatan (consent) negara. Namun demikian, dalam wacana dan praksis mutakhir konsep kedaulatan negara telah mengalami perubahan; sehingga kedaulatan negara dalam pengertian yang absolut tidak dapat dipertahankan lagi (Michael J Struett, 2005: 70- 180 ).

\section{Perolehan Kedaulatan Menurut Hukum Internasional}

Secara tradisional dikenal lima cara yang dapat dilakukan oleh negara untuk memperoleh kedaulatan atas suatu wilayah. Kelima cara tersebut adalah dengan pendudukan (occupation); preskripsi (prescription); cessi (cession); akresi (acretion) dan penaklukan (conquest) . Pendudukan atau okupasi merupakan konsep yang berasal dari dan didasari oleh hegemoni (Western Sahara Opinion: ICJ Rep. 1975, 12 )

Namun demikian, setelah berakhirnya Perang Dunia II dan pembentukan Organisasi Internasional PBB, telah muncul suatu paradigma dan kerangka internasional yang baru yang menggugat serta menggantikan pandangan-pandangan tradisional dalam memaknai cara-cara perolehan kedaulatan oleh suatu negara terhadap suatu wilayah (Jenik Radon, 2004: 195 ). Negara-negara baru yang lahir dari proses memerdekakan diri dari penjajahnya telah muncul menjadi pemangku kepentingan (stake holders) dalam hubungan internasional maupun organisasi internasional PBB. Proses pemberdayaan melalui pemerdekaan diri dari negara penjajah ini telah memperoleh penguatan dan penegasan dari PBB.
Sejak berdirinya organisasi internasional PBB, perlu dikemukakan beberapa hal penting berkaitan dengan cara-cara tradisional dalam hal perolehan kedaulatan teritorial oleh negara sebagai berikut

Pertama, hukum internasional modern terutama sejak berdirinya PBB, telah melarang penggunaan kekerasan dalam hubungan internasional sebagaimana ditegaskan dalam Piagam PBB. Perolehan kedaulatan atas suatu wilayah tertentu melalui penaklukan dengan cara kekerasan merupakan cara yang tidak dapat dibenarkan dan ilegal. Perolehan kedaulatan atas suatu wilayah tertentu yang terjadi sebelum berdirinya PBB ditetapkan berdasarkan hukum antar waktu (intert-temporal law).

Kedua, perolehan dan penerapan kedaulatan oleh suatu negara terhadap suatu wilayah tertentu diatur oleh dan didasarkan pada hak untuk menentukan nasib sendiri (right of self-determination).

Ketiga, dalam kerangka hukum internasional kontemporer, penggunaan caracara kekerasan dalam hubungan internasional tidak dapat dibenarkan ; kecuali, dalam halhal tertentu yang didasari oleh alasan-alasan kuat dan sah menurut hukum internasional.

\section{Kedaulatan Negara dalam Hubungan antar Negara}

Dalam kerangka hubungan internasional, khususnya dalam hal keanggotaan di dalam organisasi internasional maka kedaulatan negara menjadi dasar dan tercermin dalam keputusan negara untuk memberikan persetujuan (consent) untuk mengikatkan diri pada organisasi internasional. Dalam konteks seperti ini, consent atau persetujuan negara adalah keputusan suatu Negara sebagai subyek yang mandiri dan bebas untuk menjadi anggota organisasi internasional ( $\mathrm{Kal}$ Raustiala, 2003: 841). Organisasi internasional mempunyai kewenangan karena adanya persetujuan secara tegas dan terbuka dari negara-negara pihak yang membentuknya atau para anggotanya. Persetujuan yang diberikan oleh negara dalam hal semacam ini tidak bersifat permanen, karena sewaktu-waktu negara dapat saja menarik kembali persetujuan yang telah diberikan.

Sejak akhir abad ke-19, secara berangsur muncul institusi-institusi internasional yang didirikan oleh Nation-States untuk memperlancar hubungan antar Nation-States 
dalam berbagai bidang. Pada akhir Perang Dunia I ( 1914-1918), masyarakat internasional membentuk suatu organisasi internasional yakni the League of Nations atau Liga BangsaBangsa dengan tujuan utama untuk menjaga kelangsungan perdamaian internasional. Dalam perkembangan berikutnya, bagi masyarakat internasional Liga Bangsa Bangsa merupakan preseden untuk mendirikan PBB setelah berakhirnya Perang Dunia II (Hassan $S$ Kartadjumena, 2008: 2 ).

Setelah Perang Dunia II berakhir, terjadi perkembangan positif bagi pertumbuhan organisasi internasional, dalam arti makin banyak organisasi internasional yang dibentuk oleh masyarakat internasional dengan portofolio yang juga makin beragam. Organisasi-organisasi internasional ini ada yang keanggotaanya bersifat universal dan ada juga yang keanggotaanya bersifat terbatas sesuai dengan tujuan masing-masing. Secara generik organisasi-organisasi internasional ini dikenal dengan istilah inter-governmental organisations atau inter-governmental agencies.

4. Kedaulatan Negara dan Globalisasi : Interdependensi Internasional

Diskursus tentang sifat dan makna kedaulatan negara serta penerapannya dalam masyarakat internasional kontempoer, terutama pada akhir abad keduapuluh dan awal abad keduapuluh satu; tampaknya telah terjadi perubahan yang perlu dicermati. Perubahanperubahan sosial, kerangka institusional dan kemajuan teknologi serta intensitas aktivitas ekonomi antar negara pada akhir abad keduapuluh dan awal abad keduapuluh satu telah mendorong terjadinya pembaharuan makna kedaulatan negara di hadapan sistem internasional. Dari sudut historis, praktik negara-negara dalam memaknai konsep kedaulatan dalam konteks hubungan internasional telah lama diperdebatkan dan perdebatan tentang hal ini masih berlangsung hingga sekarang (Kal Raustiala, 2003 : 842 ).

Pada saat bersamaan, dewasa ini dapat dikemukakan bahwa investasi dan perdagangan internasional menjadi kekuatan utama dalam menggerakkan dan mengintensifkan hubungan internasional; terutama sejak terbentuknya organisasi perdagangan dunia World Trade Organization (WTO) beserta ketentuan-ketentuan hukum internasional yang dihasilkan oleh organisasi tersebut. Senyampang fenomena semacam itu, dewasa ini juga terjadi proses interdependensi legal antara sistem hukum domestik dengan sistem hukum multilateral yang dibangun dan diterima oleh masyarakat negara-negara pada aras regional maupun internasional.

Dalam sejarah antar bangsa, dan praktik kenegaraan, keterkaitan antara kedaulatan (sovereignty) dan hak menentukan nasib sendiri suatu bangsa (national self-determination) seringkali menjadi sumber ketegangan dan bahkan konflik dengan kekerasan di berbagai wilayah negara (Paul R.Williams and Francesa Jannotti Pecci, 2004 : 40). Pada satu sisi, kedaulatan bagi pemegang kekuasaan merupakan hal yang dianggap sudah pasti dan given dan merupakan landasan untuk memperoleh otoritas dan mengimplementasikan otoritas tersebut. Sementara pada sisi yang lain, hak menentukan nasib sendiri bersifat revolusioner, digerakkan oleh komitmen dan kohesi kelompok penduduk yang berada di wilayah tertentu dan merasa memiliki kesamaan identitas.

Secara teoritik terdapat dua landasan yang berbeda yang perlu dikemukakan yang masing-masing mendasari kedaulatan negara (sovereignty) dan hak menentukan nasib sendiri (self determination). Landasan teoritik tersebut dikenal dengan istilah atau pendekatan "sovereignty first" dan "self-determination first". Pendekatan yang mengutamakan kedaulatan ("sovereignty first"), terutama dilandasi oleh prinsip kedaulatan negara (sovereignty), integritas teritorial (territorial integrity) dan kemerdekaan politik (political independence). Pendekatan sovereignty first, pada umumnya didasari oleh keinginan negara untuk menjaga dan mempertahankan integritas teritorialnya, atau oleh pihak ketiga yang khawatir bahwa jika muncul terlalu banyak negara dalam masyarakat internasional dapat menimbulkan instabilitas internasional. Pendekatan yang mengutamakan hak menentukan nasib sendiri (self determination first) didasari oleh prinsip hukum yang berkaitan dengan hak untuk menentukan nasib sendiri dan perlindungan hak-hak asasi manusia (protection of human rights). Dalam sejarah internasional, pendekatan "self-determination first" yang muncul terutama dalam konteks dekolonisasi didasari oleh argumen bahwa sekelompok orang yang memiliki kesamaan identifikasi, berhak secara kolektif untuk menentukan nasibnya sendiri dengan cara demokratik dan bebas dari tindakan penyiksaan dan penganiayaan secara sistematis. 
Seiring perkembangan yang terjadi di dalam masyarakat internasional, didapati dinamika yang sangat menarik tentang makna kedaulatan negara sebagai penyangga sistem hukum internasional. Salah satu pandangan teoritik yang relevan dengan makna kedaulatan negara dalam sistem internasional adalah "relational sovereignty". Teori "relational sovereignty" beranggapan bahwa kedaulatan dalam masyarakat internasional kontemporer telah berkembang menjadi suatu konsep yang bersifat "relational" dan terbuka; bukan suatu konsep yang "insular" atau sempit dan tertutup. Dalam pandangan teoritik ini, konsep kedaulatan sebagai hal yang bersifat terbuka, lebih mengutamakan pada kemampuan untuk menjalin hubungan keluar, daripada hak untuk bertahan dari pengaruh pihak eksternal (James J Sheehan, 2006: 42-43). Kedaulatan bukan merupakan dalih bagi otoritas negara untuk menutup diri dari proses interaksi dengan pihak eksternal. Kapasitas untuk menjalin hubungan dan berinteraksi dengan pihak eksternal justru memperkuat makna kedaulatan negara yang bersangkutan.

Fenomena menarik yang terjadi di dalam masyarakat internasional terutama sejak berdirinya organisasi internasional PBB adalah bahwa penghormatan dan pemenuhan serta penegakan hak asasi manusia tidak lepas dari perhatian dan kepedulian masyarakat internasional. Ada kecenderungan pada tingkat global yang menunjukkan bahwa, permasalahan yang berkaitan dengan penegakan hak-hak asasi manusia di suatu negara tidak dapat dilepaskan dari domain hukum internasional. Hal ini bisa dirujuk pada Pasal 55 dan 56 Piagam PBB, yang mewajibkan setiap anggotanya untuk meningkatkan penghormatan dan penegakan hak-hak asasi manusia. Bahkan penghormatan dan penegakan hak asasi manusia merupakan tujuan yang dirumuskan dalam Piagam PBB (Henry $J$ Steiner and Philip Alston, 2000: 141-142). Dalam konteks demikian, yurisdiksi domestik tidak dapat dijadikan dalih untuk tidak menegakkan dan mengungkap terjadinya pelanggaran hak asasi di suatu wilayah negara (DJ Harris, 1991: 604). Oleh karena itu, kedaulatan negara harus diletakkan dalam konteks dan dikaitkan dengan prinsip-prinsip umum hukum internasional, seperti ; larangan penyalahgunaan hak (prohibition of abuses of rights), penghormatan terhadap kedaulatan negara lain, due diligence, "minimum standards of civilisation", dan lain-lain (Alain Pellet, 2000 :4).
Keberadaan negara sebagai unsur terpenting dalam sistem masyarakat internasional tetap tidak terbantahkan. Namun demikian, kiranya dapat dikemukakan catatan bahwa telah terjadi perubahan pada sifat kedaulatan yang melekat pada keberadaan negara-negara tersebut. Sebagai contoh nyata yang merepresentasikan gejala semacam ini adalah apa yang terjadi di negara-negara anggota Uni Eropa (European Union). Di dalam wilayah internal Uni Eropa, orang, barang dan modal dapat bergerak secara bebas dan tidak dapat dilakukan limitasi berdasarkan batasbatas teritorial negara-negara anggota organisasi tersebut. Negara-negara anggota Uni Eropa juga telah mengintegrasikan sistem moneter di antara mereka serta mengikatkan diri pada perjanjian-perjanjian internasional regional yang berlaku di seluruh wilayah negara anggota.

Pada lingkup yang lebih luas gejala yang sama dapat dicermati dalam proses liberalisasi ekonomi di seluruh dunia yang diprakarsai dan difasilitasi oleh Organisasi Perdagangan Internasional (World Trade Organizations/ WTO). Liberalisasi ekonomi internasional yang diprakarsai oleh WTO tersebut telah mendorong terjadinya proses globalisasi. Globalisasi yang terjadi di seluruh dunia merupakan proses internasionalisasi komunikasi, perdagangan dan organisasi ekonomi (Ross P Buckley, 2002: 2). Proses globalisasi yang menjadi gejala yang harus dihadapi oleh negara-negara dan bangsa-bangsa di seluruh wilayah dunia, terjadi karena dorongan perkembangan kapitalisme internasional dan didalamnya juga menyertakan transformasi budaya dan struktur sosial bagi masyarakat yang semula merupakan masyarakat non kapitalis, dan bahkan masyarakat yang masuk dalam kategori preindustrial societies.

Proses globalisasi pada aspek ekonomi dapat dicermati dari perjanjian perdagangan internasional yang berlaku pada level hubungan antar negara, sistem hukum nasional, maupun kerangka relasi individual. Pada saat yang sama juga ditandai dengan meningkat-pesatnya volume perdagangan internasional serta meningkatnya interdependensi ekonomi di antara negara-negara. Modal, pangsa pasar dan korporasi telah mendorong terjadinya kompetisi yang merujuk pada prinsip "equal treatmenf'. Dalam hal hubungan perdagangan internasional yang dibangun dan didasari oleh ketentuan-ketentuan hukum yang proses pembentukan dan implementasinya difasilitasi 
oleh WTO, masyarakat internasional mendasarkan diri pada kerangka hubungan para pihak yang bersifat "rule of law oriented". Hubungan ekonomi antar negara harus dilakukan dengan menjunjung tinggi prinsip "legal certainty"; "due process through judicial procedures". Pada kenyataannya, setiap negara anggota WTO harus mengikuti kecenderungan dan menerima "progressive judicialisation" serta mentaati proses hukum yang mengandalkan pada "law enforcement without 'mean of pressing". Dari perspektif ekonomi internasional pendekatan yang mengedepankan "rule of law oriented approach" tersebut dianggap lebih menjamin security dan predictability bagi para pihak.

Sementara itu, dari perspektif yang lain (bottom-up), globalisasi juga digerakkan oleh lapisan akar rumput (grass-roots) atau masyarakat yang termotivasi oleh kesetaraan (equality) dan kerjasama lintas batas. Dalam hal ini, negara-negara sebagai anggota masyarakat internasional juga tidak dapat menghindar dan harus menerima gejala di mana norma-norma hak asasi manusia dikembangkan dan disebar-luaskan ke seluruh dunia oleh gerakan-gerakan masyarakat sipil, organisasi kemanusiaan, maupun organisasi internasional yang relevan. Gerakan-gerakan semacam ini sekarang juga mempertanyakan pandangan "status quo" yang menempatkan kedaulatan negara sebagai konsep yang absolut. Pemajuan dan perkembangan dan norma-norma hak asasi manusia, dengan demikian, juga merupakan bagian dari proses globalisasi yang melanda setiap negara sebagai anggota komunitas internasional. Seperangkat norma dan nilai-nilai yang bersumber pada kemanusiaan dan perlindungan hak asasi manusia telah diakui dan diterima sebagai gejala universal, meskipun terdapat perbedaan dan variasi dalam implementasinya antara negara satu dengan lainnya.

Gejala-gejala tersebut dapat diprediksi akan menimbulkan tantangan baru dan menumbuh-kembangkan norma-norma hukum internasional yang harus diperhatikan dan ditaati oleh negara-negara sebagai anggota komunitas internasional. Pada saat yang bersamaan interpretasi tradisional yang menganggap kedaulatan negara sebagai konsep yang absolut juga mulai dipertanyakan (Peter J Spiro, 2000 : 567-590; Joseph Stromberg, 2004: 29-93 ). Hak prerogatif negara-bangsa (nation-state) yang ditumpukan pada konsep kedaulatan akan berhadapan dengan dan dipengaruhi oleh norma-norma yang diartikulasikan, disebarluaskan dan diterapkan secara transnasional ataupun internasional.

Pada dua dekade terakhir abad keduapuluh dan memasuki abad ke duapuluh satu, kiranya dapat disaksikan bahwa pemahaman tentang kedaulatan sebagai konsep yang absolut harus dipertimbangkan kembali. Kegagalan otoritas nasional dalam mengelola dinamika politik dan memberikan perlindungan terhadap hak asasi manusia warganya sebagaimana yang terjadi di wilayah-wilayah Myanmar, Angola, Afghanistan, Somalia dan bekas Yugoslavia, merupakan fakta yang tak terbantahkan bahwa negara tidak dapat menutup diri dari bantuan kemanusiaan dari masyarakat internasional dengan dalih atau atas nama kedaulatan. Kedaulatan negara tidak dapat dijadikan perisai (shield) oleh otoritas nasional untuk mencegah bantuan eksternal kepada warga di negara yang bersangkutan yang memerlukan bantuan dan perlindungan internasional (Rebecca Devitt, 2011: 1-4; Peter Lee, 2012: 1-10; Pravit Rojanaphruk, 2012: 1-2).

Kedaulatan bukan merupakan fakta atau kondisi yang sifatnya statis. Kedaulatan lebih merupakan proses atau serangkaian tindakan dan proses. Jika terdapat suatu negara yang mengalami proses dan telah menjelma menjadi suatu negara yang gagal (a failed state), ketika di dalamnya telah terjadi perpecahan secara fisik, budaya, ekonomi, dan politik, terceraiberai ke dalam banyak non state actors serta telah kehilangan kapasitas untuk melaksanakan koordinasi maka negara tersebut telah kehilangan kedaulatannya (Joseph MacKay, 2006 ).

Dari perspektif akademis, kiranya perlu dikembangkan wacana visioner untuk menemukan pemaknaan yang sahih mengenai konsep kedaulatan negara pada saat sistem internasional telah memasuki era interdependensi di antara negara-negara dalam sistem internasional terkini. Negara sebagai elemen utama dalam masyarakat internasional tidak tergantikan, namun, otoritas nasional di negara yang bersangkutan mengemban mandat dan tanggungjawab untuk memajukan warganya, meningkatkan kemakmuran dan menjaga kebebasannya, mengelola konflik yang terjadi di antara mereka, serta mengembangkan kerjasama internasional untuk meningkatkan kualitas kehidupannya. Dalam bahasa yang 
lain adalah merekonstruksi kedaulatan sebagai tanggung jawab (sovereignty as responsibility); menempatkan negara sebagai agen dan manifestasi dari kedaulatan rakyat yang mengemban tugas untuk meningkatkan kondisi kehidupan warganya, dan harus mempertanggungjawabkan mandatnya secara internal terhadap warga negaranya maupun secara eksternal kepada anggota komunitas internasional (Hussein Solomon, 2005: 1 ). Kedaulatan negara harus memiliki makna yang positif. Otoritas nasional berkewajiban memberikan perlindungan dan bantuan kepada warganya. Dengan demikian konsep kedaulatan negara juga berhubungan erat dengan dan didukung oleh konsep " Responsibility to Protect" yang dikembangkan masyarakat internasional (Deng, 2006: 220).

Pada saat bersamaan, dewasa ini terdapat gejala di dalam masyarakat internasional untuk melakukan implementasi kedaulatan negara berdasarkan konsep "Multilateral Pooled Sovereignty" dan internasionalisasi prinsip-prinsip universal. Berdasarkan konsep "Multilateral Pooled Sovereignty"; berarti negara-negara berdaulat bertindak bersama dengan cara-cara kedaulatan yang dimiliki masing-masing negara secara bersamaan disatukan melalui badan, institusi, organisasi dan jaringan (networks) baik secara formal maupun informal. Institusi, badan, atau regulator pengambil tindakan yang diperlukan adalah suatu badan yang dibentuk secara multilateral tetapi memiliki satu otoritas yang mandiri. Konsep semacam ini dewasa ini dimanifestasikan dalam berbagai badan internasional yang telah diakui dan diterima otoritasnya oleh masyarakat internasional seperti Badan-Badan PBB semacam World Health Organisastion ( WHO), dan badanbadan internasional lainnya seperti World Trade Organisation, International Bank for Reconstruction and Development (the World Bank) dan International Monetary Fund ( IMF). Sementara itu, internasionalisasi prinsip-prinsip universal dapat dipahami dengan melihat pengakuan dan implementasi nilai-nilai hak asasi manusia. Prinsip-prinsip universal yang berupa nilai-nilai hak asasi manusia diterima dan diimplementasikan oleh lembaga-lembaga internasional, transnasional dan supra nasional. Implementasi nilai-nilai universal hak asasi manusia secara internasional tidak bergantung pada adanya persetujuan (consent) nyata dari suatu negara manapun tetapi mengacu pada kebenaran nilai-nilai universal hak asasi manusia .

\section{Simpulan}

Kedaulatan bersifat "relational" dan terbuka; bukan suatu konsep yang "insular" atau sempit dan tertutup. Kedaulatan bukan merupakan fakta atau kondisi yang sifatnya statis. Kedaulatan lebih merupakan proses atau serangkaian tindakan dan proses. Negara yang berdaulat harus memiliki kapasitas untuk melakukan koordinasi dan menjaga supaya tidak terjadi perpecahan secara fisik, budaya, ekonomi, politik, dan atau tercerai-berai ke dalam banyak non state actors sehingga mengalami proses dan menjelma menjadi suatu negara yang gagal (a failed state). Dewasa ini pemahaman kedaulatan sebagai konsep yang absolut harus dipertimbangkan kembali. Kegagalan ortoritas nasional dalam mengelola dinamika politik dan memberikan perlindungan terhadap warganya di berbagai wilayah dunia merupakan bukti bahwa negara tidak dapat menutup diri dari bantuan internasional dengan dalih atau atas nama kedaulatan. Kedaulatan negara tidak dapat dijadikan perisai (shield) oleh otoritas nasional untuk mencegah bantuan internasional kepada warga di negara yang memerlukan bantuan dan perlindungan internasional.

Dari perspektif akademis, perlu dikembangkan wacana visioner untuk menemukan pemaknaan yang sahih mengenai konsep kedaulatan negara pada saat sistem internasional telah memasuki era interdependensi di antara negara-negara dalam sistem internasional terkini. Kedaulatan ditempatkan ditangan rakyat, vis a vis pemerintah dan berkaitan dengan prinsip-prinsip umum hukum internasional. Negara sebagai elemen utama dalam masyarakat internasional tidak tergantikan, namun, otoritas nasional mengemban mandat dan tanggungjawab untuk memajukan warganya, meningkatkan kemakmuran dan menjaga kebebasannya, mengelola konflik, serta mengembangkan kerjasama internasional. Dalam bahasa yang lain adalah merekonstruksi kedaulatan sebagai tanggung jawab (sovereignty as responsibility); menempatkan negara sebagai agen dan manifestasi dari kedaulatan rakyat, yang mengemban tugas untuk mensejahterakan warganya, dan harus mempertanggungjawabkan mandatnya secara internal maupun secara eksternal kepada komunitas internasional. 


\section{Daftar Pustaka}

Anderson, Kenneth. 2005. "Squaring the Circle? Reconciling Sovereignty and Global Governance Through Global Government Networks”. (Book Review : A New World Order, by Anne Marie Slaughter). 118 Harvard Law Review, 2005 . Cambridge : Harvard Law School.

Bartelson , Jens. 2006. "The Concept of Sovereignty Revisited”. (17 ) European Journal of International Law, Vol. 17. No.2. Oxford: Oxford University Press.

Bledsoe, Robert L \& Boczek, Boleslaw A .1987. The International Law Dictionary.Oxford : Clio Press.

Brownlie, Ian. 1990. Principles of Public International Law. Fourth Edition. Oxford : Clarendon Press.

Buckley, Ross P. 2002. "Globalization, Capital Markets and Human Rights". New England Journal of International Comparative Law, (2002) Vol. 8. No. 2 . Boston: New England University Law School.Dixon, Martin \& Mc. Corquodale.

Robert. 2000. Cases \& Materials on International Law; Third Edition. London: Blackstone Press Limited.

Deng, Francis M. 2006. "Divided Nations; the Paradox of National Protection". The ANNAL of American Academy of Political and Social Science, 603, January 2006. Philadelphia : the University of Pennsylvania .

Devitt, Rebecca . 2011, September 6. "Burma, Bangladesh and the Rohingya: a Failure to Protect?”. eInternational Relations . http://www.e-ir.info/2011/09/06/burma-bangladesh-and-the-rohingya-a-failure-to-protect/ [6 Januari 2013].

Harris, D J. 1991. Cases and Materials on International Law. London: Sweet \& Maxwell.

Hingorani, R.C. 1982. Modern International Law. Second Edition. New Delhi: Oxford \& IBH Publishing Co.

Kahn, Paul W. 2004. "Balance of Power: Redefining Sovereignty in Contemporary International Law". Commemorative Issue, Articles. THE QUESTION OF SOVEREIGNTY. (40) Stanford Journal of International Law ; Summer 2004. Stanford : University of Stanford.

Kartadjumena, Hassan S. 2008. "Pergeseran dalam “ International Economic Governance” : Implikasi Kebijakan Publik dan Persiapan Profesi Hukum”. Paper. disampaikan dalam ceramah di Fakultas Hukum UGM 1 Maret 2008. Yogyakarta: Fakultasb Hukum UGM.

Lee, Peter. Tt. "Burma Washes Its Hands of the Rohingyas". International Policy Digest. http:// www.internationalpolicydigest.org/2012/11/19/burma-washes-its-hands-of-the-rohingyas/. [7 Januari 2013].

MacKay, Joseph. 2006. State Failure,: "Actor Network Theory, and the Theorisation of Sovereignty”. BSIS Journal of International Studies, Vol. 3 2006. Brussels : University of Kent's Brussels School of International Studies.

Marcos, Miguel González. 2003. The Search for Common Democratic Standards Through International Law. Washington: Heinrich Böll Foundation North America .

Nagan, Winston P, \& Hammer, Craig. 2004. "The Changing Character of Sovereignty in International Law and International Relations”. 43 Columbia Journal of Trans-national Law, 2004. Columbia: University of Columbia.

Pellet, Alain . 2000. "State Sovereignty and the Protection of Fundamental Human Rights: an international law perspective”. ' Pugwash Occasional Papers, I: i: February 2000. http://www.pugwash.org/ publication/op/opv 1n1. htm. [10 Juli 2006, Jam 11.45 WIB].

Radon, Jenik. 2004. "Sovereignty : A Political Emotion, Not A Concept". (40.) Stanford Journal of International Law. Commemorative Issue: Balance of Power: Redefining Sovereignty in Contemporary International Law Commemorative Introduction, Summer 2004. Stanford: University of Stanford. 
Raustiala, Kal. 2003. "Rethinking the Sovereignty Debate in International Economic Law". (6 ) Journal of International Economic Law, December, 2003. Pennsylvania: University of Pennsylvania Law School.

Rojanaphruk, Pravit . 2012, June 12. "Call for UN to intervene in Rohingya 'genocide"' . The Nation Asia News Network. http://www.asianewsnet.net/ home/news. php? id=31717 [6 Januari 2013 Jam 9.45 WIB.].

Sarooshi, Dan. 2004. "The Essentially Contested Nature of the Concept of Sovereignty : Implications For the Exercise by International Organizations of Delegated Powers of Government" . (25) Michigan Journal of International Law, Summer 2004 : Symposium: Diversity or Cacophony?: New Sources of Norms in International Law. Michigan : University of Michigan .

Sheehan , James J. 2006. "The Problem of Sovereignty". The American History Review Vol. III No 1 February 2006. Oxford: Oxford University Press. 